\title{
Simicskó István:
}

\section{A HAZAFISÁG KIHÍVÁSAI ÉS PRÓBATÉTELEI A 21. SZÁZADBAN}

DOI: $\underline{10.35926 / \mathrm{HSZ} .2021 .1 .5}$

ÖSSZEFOGLALÓ: Magyarország Kormánya az 1257/2018. (VI. 4.) határozatával a hazafias és honvédelmi nevelésért felelős kormánybiztost nevezett ki jelen tanulmány szerzőjének személyében. Feladatai között szerepel a honvédelmi nevelés kormányzati stratégiájának kidolgozása. A honvédelmi nevelés a hazafiságra nevelés komplex feladatrendszerébe integrálódik. Az alábbiakban közreadott írás a hazafiasságra nevelés rendszerkörnyezete elemzésének részeként bemutatja korunk legjelentősebb kihivásait és kockázatait, amelyek - megtévesztő módszerekkel - veszélyt és egyben próbatételt jelentenek, föként a fiatal nemzedék tagjai számára magyarságuk megélésében. A szerző tanulmánya konklúziójaként megerősíti: a 21. század biztonsági kihívásaival, kockázataival szemben-legyen azokeredete a globalizáció, vagy éppen az új típusú hadviselés - a hazaszeretet, a nemzeti összetartozás érzésének erösítése lehet az ellenük való védelem alapja.

KULCSSZAVAK: honvédelem, hazaszeretet, globalizáció, migráció, hibrid hadviselés, nemzetállamok

\section{A HAZAFISÁGRÓL}

A hazafiság összetett tartalmú erkölcsi kategória, amelynek alapját érzelmi és tudati elemek alkotják. Az erkölcs az írott és íratlan szabályaival az egyik legerősebb társadalmi norma. A történelem folyamán az erkölcsi normák gyakran változtak, sőt rövid távon is formálódnak, akár egyidejűleg meg is férnek egymás mellett. Maga a hazafiság tartalma, jelentése is változott a különböző korszakokban. A hazafiság (patriotizmus) fogalma - patris - görög eredetü, azonban a görögök kötődése nem a mai értelemben vett nemzethez (etnoszhoz), hanem a poliszhoz kapcsolódott, egy adott területi egységhez való kötődést, annak kormányzatához, berendezkedéséhez való viszonyulását, felvállalását jelentette. A magyar patriotizmus jegyei ezzel szemben nemzeti kötődést mutatnak, és érzelmi pillérének történelmi távon is konstans eleme a hazaszeretet. Ezt fejezi ki Eötvös József, A zsidók emancipációja címü múvéből való idézet: „A haza nem azon darab föld, melyen születünk. [...] A haza több. Azon hely, melyen magunkat szabadoknak érezhetjük, melyben csak hasonlókat találunk, melynek története dicsőségünk, virágozása boldogságunk, jövője reményünk; hol házunk áll, hol homlokunk izzadságával munkált vetéseink zöldellnek, hol idegeneknek nem tartatunk, s nincs éldelet, melyet legalább reménylenünk nem lehetne; ez a haza, ez az, miért csak a gyáva nem áldozza életét, s kinek ezt nem adók, attól áldozatokat kívánni kegyetlenség."’1

1 Eötvös József: A zsidók emancipációja. https://mek.oszk.hu/05900/05920/html/gmeotvosj0002.html (Letöltés időpontja: 2019. 10. 22.) 
A reformkor tekinthető a nemzeti ébredés meghatározó időszakának, amelyben a magyarság legnemesebb érzései fejeződtek ki és álltak össze egységes nemzeti programmá; a hazafiság olyan természetes érzület volt, amely lelkesített és magasabb célok érdekében való összefogásra ösztönözte a kortársakat. A magyar nemzet hagyományainak legjobb elemeit gyúrta össze egy közösen vállalható nemzettudattá, amely a jövőt építő folyamatok biztos alapját képezte. E kor tárgyi és szellemi hagyatékára ma is büszkék vagyunk.

\section{A HAZAFISÁG KIÉRLELŐDÖTT ÉRZELMI-TUDATI ÁLLAPOT}

Hiába nosztalgiázunk a reformkor sikerein, ha közben rezignáltan azonosulunk olyan véleményekkel, hogy mai korunk folyamatai nem kedveznek a hazafiság vállalásának, vagy ha mégis, akkor ránk süthetik a nacionalista vagy a soviniszta bélyeget. A hazafiság nem egy kívülről jövő, időről idöre külsőnket megújító divatirányzat, hanem ezeréves történelmünk próbatételei során: „,a haza iránt érzett szeretet, mely tudatossá téve az erkölcsi erények egyik legfőbbike."2 A tudatos hazafiság soha nem válhat idejétmúlttá vagy elavulttá, a valódi hazafiság nem lehet sem nacionalista, sem soviniszta. Az igazi patriotizmus a saját nemzeti értékek tiszteletére nevel, más nemzetek megsértése nélkül. Söt, ezen keresztül tudja egy magyar ember is tisztelni más népek kultúráját, nyelvét, szokásait. Kétségtelen, hogy a történelmi korszakok összevetésében a reformkor közege kedvezőbb volt a progresszív nemzeti szocializációs folyamatoknak, mint a lopakodó kihívásokkal teli 21. század. Napjainkban a legnagyobb kihívásokat - az egyén és a nemzet szintjén egyaránt -a globalizáció, az illegális migráció és az újkori birodalmiság politikája jelenti. Sőt a biztonságot veszélyeztető tényezők intenzitás szerinti kategorizálása alapján az illegális migráció túlmutat a kihívás fokozaton, és a kockázat kategóriába tartozik. Korlátlanul teret engedve az előzőekben felsorolt kihívásoknak és kockázatoknak a felnövekvő nemzedék számára kiüresedett fogalommá válhat a haza, a hazafiság, a hazafias és honvédelmi nevelés jelentése.

\section{GLOBALIZÁCIÓ}

A globalizáció a nagy földrajzi felfedezésekkel indult világhódító útjára, és történelmi korokon át folytatódott kiteljesedése, amelynek üteme különösen a 20. században erősödött fel és a világpiac intézményesült kialakulásával - az időpont a WTO World Trade Organization (Kereskedelmi Világszervezet) 1995-ös létrehozására datálódik - vált valóban világméretűvé. Kiterjedését tekintve globálisnak értelmezhetjük mindazokat a társadalmi, gazdasági és környezeti folyamatokat, amelyek hatása nem szűkíthető le országos, regionális vagy kistérségi szintre, hanem a Föld egészére kiterjed. Tartalmában és céljában olyan folyamatok ezek, amelyek során a világban a nyugati civilizáció hatására egységesedés megy végbe a gazdaságban, a pénzügyi és kereskedelmi életben, az épített környezetben, a kultúrában és folytatható a felsorolás egészen az egyes ember életstílusáig bezárólag. A következmény egyfajta monokultúra: hasonló, a fogyasztói társadalmat jellemző életmód; ugyanazok a bevásárlóközpontok, szállodák, zsúfolt nagyvárosok, azonos termékek, ételek (McDonald’s), filmek, zenék, infotechnológiák, mint a világ sok más szegletében. Egyesek szerint mindez áldás, az egységes jóléti világhoz vezető út, mások szerint átok. Valóban a mai kor sajátos időszaka az emberiségnek: egy olyan világban élünk, amelyben a globalizáció mint egy mindenen áthatoló folyamat egyaránt teremt új és tüntet el korábban meglévő értékeket.

2 http://www.kislexikon.hu/hazaszeretet.html (Letöltés időpontja: 2019. 10. 22.) 
Ezért sem lehet a globalizációt egyoldalúan károsnak vagy hasznosnak minősíteni. A globalizáció sokarcú, sokjelzős folyamat, amely elől bezárkózni legalább olyan rossz döntés, mint korlátlanul beengedni. Főként a gazdasági folyamatok elemzése azt mutatja, hogy a világnak éppen azok a népei a legszegényebbek, amelyek kimaradtak a globalizáció folyamatából. A diktatúrák - Észak-Korea, Kuba és a legtöbb afrikai ország - kapcsolódnak be legkevésbé - értelemszerüen ezek a világ legszegényebb országai. Egyoldalúan vagy felszínesen mérlegelve a globalizáció komplex hatásmechanizmusait, okkal hitetlenkedhetünk: mi rossz van abban, ha a legmodernebb technikáknak és technológiáknak köszönhetően könnyen bekapcsolódhatunk a globális világgazdaság vérkeringésébe, ráadásul mindezekhez a fejlett világ bankjai készségesen nyújtanak forrásokat is? Önmagában a modern technikák és technológiák apportálásában még semmi rossz nincsen, sőt hasznos, ugyanakkor ez csak egy folyamat kezdete, amelyhez még számos „,mellékhatás” kapcsolódik. A gazdasági globalizáció „,betegtájékoztatóján” azonban nincsenek feltüntetve a mellékhatások. A gazdasági globalizáció fő haszonélvezői, támogatói a nemzetek feletti cégbirodalmak és pénzintézetek, amelyek kezében egyre több és kevésbé ellenőrizhető hatalom összpontosul. A folyamat részeként a nemzetállami keretek egyre kevésbé alkalmasak a gazdasági és társadalmi folyamatok kezelésére, számottevően csökken a helyi társadalmak, kormányok és közösségek szuverenitása az állampolgárok életét érintő legfontosabb kérdésekben. A globalizációnak ez a nemzetállamok müködésére kiterjedő negatív hatása van leginkább befolyással jelen írás témájára, a hazafiság kérdéskörére.

Az európaiak globalizációról alkotott véleménye vegyes: ${ }^{3}$

- 37\% szerint a globalizáció országuk identitását gazdagító tényező;

- 53\% szerint országuk identitását fenyegető tényezö;

- 9\%-nak_nincs véleménye;

- 55\% szerint a globalizáció összességében lehetőséget jelent;

- 45\% szerint összességében fenyegetést jelent;

- 35\% százalék aggódik gazdasági kilátásai miatt.

A globalizáció egyik vadhajtásának tekinthető a kozmopolitizmus. A kozmopolita kifejezés az Idegen szavak gyüjteménye ${ }^{4}$ szerint:

- világpolgár, az egyetemes emberi haladás iránt elkötelezett polgár, föleg értelmiségi;

- olyan személy, akit népéhez, nemzete kultúrájához szorosabb szálak nem füznek, aki bárhol a világon könnyen alkalmazkodik;

- biológiában: a Föld legtöbb részén elterjedt élőlény.

Számtalanszor találkozhatunk azzal, hogy világpolgár jelzővel illetnek ismert személyeket, példaképnek is beállítva őket. A definíció okán joggal tehetjük fel a kérdést: Lehet-e jó hazafi, akit népéhez, nemzete kultúrájához szorosabb szálak nem füznek? Csak remélni tudom, hogy a definíció hibás és a mi világpolgáraink úgy teljesítik az „egyetemes emberi haladás iránt elkötelezett” küldetésüket, hogy megőrizve magyarságukat, kötődnek népünkhöz, nemzetünkhöz, kultúránkhoz és lelkükben, szívükben, tudatukban elsősorban patrióták és nem kozmopoliták, mert ,,a haza minden előtt”. A globalizáció és a kozmopolitizmus féktelen támogatói gyakran érvelnek a haza szolgálatának ellenpontjaként az egyetemes emberi haladás szükségességével, prioritásával. A haza és haladás szóösszetétel használatának,

\footnotetext{
Vitaanyag a globalizáció elönyünkre fordításáról. Európai Bizottság $\operatorname{COM}(2017)$ 240. 2017. 05. 10. https://ec. europa.eu/commission/sites/beta-political/files/reflection-paper-globalisation_hu.pdf (Letöltés időpontja: 2019. 10. 17.)

4 https://idegen-szavak.hu/kozmopolita (Letöltés időpontja: 2019. 10. 22.)
} 
illetve jelszóvá történő összekapcsolásának két évszázados története van, és Kölcsey Ferenc nevéhez füződik: „,Jelszavaink valának: haza és haladás.” Nagyon meggyőző iránymutatást ad ebben a kérdéskörben Csejtei Dezső filozófiatörténész, egyetemi tanár közelmúltban megjelent írása, bemutatva a Kölcsey ihlette szóösszetétel használatának hatalomfüggő manipulációit, aktualizálva a globalizáció és a kozmopolitizmus mesterkedéseire. ${ }^{5}$ Kölcsey annak idején még arra akarta felhívni kortársai figyelmét, hogy a haza ügyének előmozdítása, a nemzeti önállóság kivívása nem valósítható meg a polgárosodást célzó alapvető reformok bevezetése nélkül. Ebben az időszakban a haza és haladás egymáshoz kapcsolódása - a haza dominanciájával - még egyensúlyban volt és harmonikusan kiegészítette egymást. Azonban később, főként a 20. században a baloldali mozgalmak hatalomra jutásának időszakában a hangsúly átbillent az ellentétébe. Ekkor már a haladás került túlsúlyba, mégpedig annak internacionalista indokával egybekötve. A szocializmus időszakában is élt egyfajta hazamitológia, a „szocialista haza” jelzős szerkezetben manifesztálva a dolgozó osztályok ahhoz való kötődését. A rendszerváltást követő időszakban eresztett gyökeret nálunk is a liberális kozmopolitizmus felfogása, amely jelentős mértékben erodálta a hazához tartozó erkölcsi normákat, köztük a haza védelmének kötelességtudatát. A haladás jelentésköre ekkor vált egyenlővé az új csodafegyverrel, a globalizációval, amelyet tetézett a multikulturalizmus erőltetése, a humanitás mázába burkolt migránspolitika. Azt gondolom, teljes mértékben azonosulni lehet a szerző konklúziójával, miszerint „....korunkban a sarkaiból kifordult haladás jelszavával szemben maga a haza, annak óvása jelenti az igazi haladást [...] S az átalakítás eme hosszú és fáradságos munkájában központi szerepre, s ezáltal új jelentésre tesz szert a haza, a nemzetállam mint a kozmopolita pusztítás szinte egyedüli ellenszere". ${ }^{\circ}$

\section{MIGRÁCIÓ}

A migráció és annak kísérőjelenségei korunk egyik legnagyobb kockázatát jelentik. A megindult újkori népvándorlás felülírt minden eddigi elképzelést. Konkrétan: Európa a török hódoltság óta nem volt ilyen mértékü, végletes szociális, kulturális és civilizációs sokkhelyzetnek kitéve, mint amit az elmúlt néhány évben történt események okoztak.

Számos nyugat-európai példa azt mutatja, hogy az évtizedek óta Európában élő bevándorlók saját mikroközösségeikben élnek, és ezen nem is akarnak változtatni. A befogadó országba érkezettek között egészen szélsőséges a megoszlása annak, hogy ki mennyire alkalmazkodik a befogadó nemzet kultúrájához, törvényeihez, vallásához. Belátható, hogy a korlátlan migráció az Európát sújtó demográfiai krízissel, a születésszám csökkenő tendenciájával párosulva rövid távon megváltoztatja és extrém esetben tagadásba kényszeríti az évezredek alatt kialakult egyetemes európai értékeket, jogot, kultúrát, vallást, és alapjaiban forgatja fel a most még többé-kevésbé szilárd alapokon nyugvó európai társadalmakat. Nem nehéz prognosztizálni ennek a folyamatnak a nemzetállamokat fenyegető biztonságpolitikai kockázatait.

\footnotetext{
5 Csejtei Dezső: A haza minden előtt. https://magyarnemzet.hu/velemeny/a-haza-minden-elott-7333160/ (Letöltés időpontja: 2019. 11. 02.)

6 Uo.
} 


\section{ÚJKORI BIRODALMI TÖREKVÉSEK}

A vezető európai politikusok körében alapvetően két, egymással gyökeresen szemben álló felfogás uralkodik a kontinens, valamivel szükebb értelemben az Európai Unió jövőjét illetően. Az egyik tábor szeretné megörizni Európa - több évezredes fejlődés eredményeképpen kialakult, a zsidó-keresztény hagyományokban gyökeredző - nemzeti értékeket tiszteletben tartó karakterét, és alapvetően a nemzetállamok együttmüködését hangsúlyozza az Unió keretei között. Ezen irányzat képviselői meg vannak győződve arról, hogy Európa akkor lehet erős, ha a tagországai erősek és egymással messzemenőkig együttműködve, ugyanakkor a saját képességeiket a legjobban kihasználva próbálnak helytállni, szuverenitásukat megtartva, és nem központi - adott esetben a nemzetek érdekeivel, hagyományaival, kultúrájával és habitusával nem összeegyeztethető - utasítások végrehajtói szerepkörébe kényszerülnek. A legjelentősebb európai államok közül az Egyesült Királyság hagyományosan az erős nemzetállamok pártján áll. A másik irányzat támogatói szerint Európa csak akkor képes azonos ütemü haladásra a világ vezető hatalmaival, ha azokhoz hasonlóan maga is szuperhatalommá, valójában újkori birodalommá válik, amely államalakulatban centralizált struktúrában születnek a döntések. Ezen elképzelések mögött tulajdonképpen az Európai Egyesült Államok létrehozásának víziója húzódik meg, amelyben a nemzetállamok jóval kevesebb szerephez jutnának, a nemzeti érdekek képviseletére minden bizonnyal kevesebb lehetőség lenne, és az évszázadok alatt vérrel és munkával kivívott nemzetállami függetlenségről való lemondást jelentené olyan célok érdekében, amelyeknek még a körvonalai is alig, a garanciájuk pedig egyáltalán nem létezik. Az Európai Unió meghatározó államai közül Németország és Franciaország szeretné leginkább elérni a szervezet központosítását.

Roger Scruton brit filozófus úgy fogalmazott: „, A nemzetállam nem a probléma, hanem a megoldás: ez zárja magába az egyedüli motivációt, melyhez a politikusok folyamodhatnak, amikor az európai projekt hatása végre az egész kontinensen érezhetővé válik."7

\section{Ú TÍPUSÚ HADVISELÉS}

Különösen a NATO szervezetébe történő belépésünk után találkozhattunk az önálló haderő, az önálló honvédelem fejlesztésének szükségszerüségét megkérdőjelező indoklásokkal, közöttük olyanokkal, mint: egyrészt a NATO úgyis megvéd, ha a szükség úgy hozza; másrészt több mint fél évszázada béke van Európában. Az előbbiek még tekinthetők ,,veszélytelen laikus megnyilatkozóknak", de azt gondolom, az újkori birodalmiság képviselői nem ebbe a kategóriába tartoznak. Ök valós veszélyt jelentenek, mert a központi hatalomnak az önálló nemzetállamok rovására való erősítése filozófiájától már csak idő kérdése eljutni az önálló haderö, az önálló honvédelem szükségességének tagadásáig. Arra a kérdésre, hogy mennyire van béke a világban, mennyire reális az állampolgárok biztonságérzete és szükség van-e a nemzetállamoknak önálló haderőre, az új típusú hadviselés alábbiakban kiemelt jellemzői is választ jelenthetnek.

A hibrid hadviselési modell a 21. század hadviselés-elméletének legújabb terméke, amely az államok közötti fegyveres összeütközés területén új gondolkodásmódot tükröz. A jelen korszak hadviselése - nevezzék azt stratégiai elrettentésnek, új generációs hadviselésnek vagy éppen hibrid hadviselésnek - azon a közös felismerésen alapszik, hogy egyfelöl nincs

7 Roger Scruton: Nélkülözhetetlen nemzetek. Magyar Szemle. Új folyam, 2013. XXII/7-8., augusztus, 52-76. 
realitása annak, hogy az államok - különösen a nagyhatalmak viszonylatában - csak katonai erővel elérjék geopolitikai céljaikat; másfelöl az érdekérvényesítésük ezen szintjén is van olyan komplex helyettesítő eszközrendszer, amely képes kiváltani, illetve limitálni a katonai eszközök alkalmazását. „, A hibrid hadviselés mint komplex stratégiai (rendszer) modell az államok, szövetségek geopolitikai céljaik érdekérvényesitésének eszközrendszere. A modell a katonai müveletek limitált alkalmazásával, és döntöen a nem katonai eröforrások és módszerek transzformációjával biztositja a geopolitikai célok elérését."8

A hibrid hadviselésben megváltozott a politika és a háború clausewitzi viszonyrendszere, amelynek lényegét - az eredeti kisebb módosításával - ,a háború a politika folytatása más eszközökkel " ismert tézis fejezi ki. A megváltozott elvek és arányok miatt joggal mondhatjuk: „,hibrid hadviseléshez kötődö politika maga a háború”, 9 amelyben az emberi dimenzió az elsődleges hadszíntér, ahol a geopolitikai célok elérése döntően új indirekt módszerekkel, a célország lakossága tudatának, elméjének befolyásolásán keresztül, a saját kormányuk ellen hangoló manőverekkel történik. A hibrid hadviselés során - annak jellegéből adódóan - elmosódik a határ a békeállapot, a minősített helyzet és a háború között, folyamatos a kölcsönös fenyegetés/fenyegetettség állapota. A „támadó fél” egy másik ország ellen, annak területén, de facto hadüzenet nélküli sajátos fegyveres küzdelmet folytat a háború szintje alatt, jellemzően a célország erőszakra hajlamos, a fennálló hatalommal szemben álló erők jól álcázott (fedett) felhasználásával. Mivel nincs hadüzenet és nem folyik fegyveres küzdelem, így lényegében nincs klasszikus értelemben vett háború, de lehetségessé válik egy kívülről irányított belső káosz elérése.

A témával összefüggésben számunkra az egyik legfontosabb kérdés, hogy Magyarországnak milyen kockázatokkal kell számolni a jövőben. Figyelembe véve hazánk geopolitikai meghatározottságát, elsősorban a szövetségi rendszerben betöltött szerepe révén válhat egy komplex hibrid fenyegetés célpontjává, amelyre csak megfelelő potenciállal rendelkező nagyhatalmak képesek. Viszont egyes hibrid komponenseken alapuló müveletek lehetőségével számolhatunk.

A NATO 2015-ben szövetségi szinten kidolgozta a hibrid hadviselés elleni stratégiát. A kapcsolódó végrehajtási terve alapján elsőként mindig a hibrid müvelet által fenyegetett vagy megtámadott tagállamnak kell reagálnia, és a nemzetközi közösségnek, felkérés esetén, készen kell állnia a segítségnyújtásra. Kvázi a hibrid fenyegetés felfedése nemzeti hatáskörbe utalt felelösség és feladat. A fenyegetés fö irányai, területei, valamint komplex jellege miatt az ellene való védekezés megköveteli a kormányzati és nem kormányzati, nemzetbiztonsági, a rend- és honvédelmi szervezetek, valamint az egész társadalom cselekvő együttmüködését. Erre utal Valerij Geraszimov tábornok, az orosz vezérkar fönökének megállapítása is: „A mai konfliktusok sajátos aktualitásává vált a lakosság, az objektumok és a kommunikáció védelme a különleges müveleti erök növekvö mértékü tevékenységétöl. Ez a feladat a területvédelem megszervezésével és müködtetésével oldható meg." ${ }^{10} \mathrm{Az}$ önkéntes területvédelmi tartalékos (ÖTT) szolgálat szervezésének folyamatában ez számunkra is releváns feladat. Pontosan az előzőekben említett új típusú biztonsági kockázatok elhárítása indokolja a korábban katonai erőre alapozott területvédelmi elvnek a gyakorlatban történő újragondolását. A területvédelem alatt ma már nem valami összefüggő, müszaki erődítési építményekkel támogatott, egységes szerkezetü területbirtoklást értünk, hanem

\footnotetext{
${ }^{8}$ Dr. Simicskó István: A hibrid hadviselés előzményei és aktualitásai. Hadtudomány, 2017/3-4., 10.

${ }^{9}$ Uo. 12.

${ }^{10}$ Uo. 15.
} 
területenként változó, a biztonságot veszélyeztető kockázati tényezők szerint differenciált, komplex védelmi erőforrások felhasználását.

Az ilyen típusú védelem egyik legfontosabb kritériuma a társadalom megfelelő felkészítése, az ország polgárai biztonságérzetének optimális szinten tartása, mert miközben optimizmussal tekintünk az emberiség jövőjére, ugyanakkor nem lehetünk nyugodtak a hibrid jelzővel „leszelídített háborútól” sem. A hibrid jelző a „könnyü és kemény erők” (hard and soft power) vegyes használatára utal; a modell prognózisa szerint a pusztítás aránya - a katasztrofális társadalmi, gazdasági és politikai következmények tekintetében - összehasonlítható egy igazi háború következményeivel.

A fentiek figyelembevételével megválaszolható a kérdés: Szükségük van-e a nemzetállamoknak önálló honvédelemre?

\section{HONVÉDELEM}

Az emberiség ismert története kezdeteiről is tudjuk, hogy az ember - mint társadalmi lény, mint közösségben élö entitás - folyamatos harcot vívott a veszélyekkel, amelyek ellen kereste a védekezés lehetőségeit, az adott kor felhalmozott tudásának minden eszközét felhasználta azok elhárítására. Nem túlzás az az állítás, hogy az emberben már a genetika szintjén kódolva van a biztonság iránti igény.

Lehet-e és mennyire lehet alapozni az emberek biztonsági igényére? Igen lehet és kell is alapozni, de annak a - már-már szlogennek számító - meghatározásnak a figyelembevételével, hogy a biztonság igénye olyan, mint a levegö, csak akkor érezzük a hiányát, ha nincs. Pedig a mai biztonsági kockázatok, fenyegetések hajlamosítanak az emberek veszélyérzetének tompítására. Gondoljunk csak az előzőekben vázolt biztonsági kihívások, kockázatok megjelenésének lopakodó jellegére.

Nemzetünk, az azt alkotó állampolgárok biztonságának legfontosabb garanciája a jól müködö honvédelmi rendszer, amelynek a szükséges szinten tartása a mindenkori kormányok törvények által meghatározott feladata.

„A honvédelem a társadalom legkiterjedtebb védelmi rendszere, a haza sorsáért viselt közös felelösségen és cselekvésen alapuló nemzeti ügy, amelyet a hon minden polgárának joga, valamint alkotmányos és erkölcsi kötelessége szolgálni."11

„A honvédelem Magyarország Nemzeti Biztonsági Stratégiája és a jogszabályok által meghatározott integrált védelmi rendszer, amely magában foglalja az ország honvédelmi képességeinek megteremtését, fenntartását, szükség szerinti mozgósitását és alkalmazását a válsághelyzetek kezelésére." 12

Az önkéntes haderő koncepcionális müködési filozófiája feltételezi a társadalom aktív közremüködését a honvédelem rendszerében. A honvédelem a Nemzeti Együttmüködés Rendszerének egyik legkifejezőbb megtestesítője, ,,amely minden magyar számára nyitott, [...] lehetőség mindenki számára és elvárás mindenki felé”. Meggyőződésem szerint a hon védelmében való személyes részvétel kérdésében rögzíteni szükséges az alábbi alapelvet: Biztositani kell, hogy minden cselekvöképes állampolgár képessége és lehetösége szerint, korra és nemre való tekintet nélkül részt vállalhasson a hon védelmének komplex feladataiban!

\footnotetext{
${ }^{11}$ Dr. Simicskó István: Az országvédelem és országmozgósítás szervezeti, hatásköri, irányítási rendszere minősített időszakokban (Történelmi korokon át napjaink hatályos szabályozásáig). Doktori (PhD-) értekezés, ZMNE, 2008.

${ }^{12}$ Uo.
} 
Egyetlen rövid magyarázat a fentiekhez: Magyarországon a nők részvétele a honvédelemben már nem kérdés, hanem tény. Ami a hadkötelezettségen kívül eső korosztályokat illeti: még a nem hadköteles fiataloknak is erkölcsi kötelességük felkészülni a honvédelemre.

\section{HONVÉDELMI NEVELÉS}

A 21. század biztonsági kihívásaival, kockázataival - legyen annak eredete a globalizáció, a migráció, vagy az új típusú hadviselés - szembeni védelem alapja a hazaszeretet, a nemzetért való felelősség és kötelességtudat erősítése. Ezt a célt szolgálja a hazafias és honvédelmi nevelés, amely az egyik legfontosabb eszköz a magyar társadalom erősítésében, védelmi képességeinek és hajlandóságának fejlesztésében annak érdekében, hogy a jelen és a jövő kihívásaira mindenkor adekvát választ tudjon adni.

Mivel a honvédelmi felkészítés az Alaptörvény által is deklarált társadalmi érdek, ezért az államnak - a polgáraitól elvárt ismeretek biztosítása érdekében - gondoskodnia kell arról, hogy az állampolgárok e tudásra szert tehessenek. Ennek keretében fontos a fiatal nemzedék hazafias nevelésének, honvédelmi identitástudata kialakításának, a honvédelem ügyéhez történő pozitív hozzáállásának folyamatos fejlesztése.

A honvédelmi nevelés a hazafiságra nevelés komplex feladatrendszerébe integrálódik. A hazafiság egy erkölcsi indíttatású magatartásmód, amelynek összetett tartalmából elsősorban a hazaszeretetet mint érzelmi és tudati motívumot emelem ki. A honvédelmi nevelés legfontosabb színterének a családot és az iskolát tekintjük, kölcsönösen kiegészítve és erősítve egymást. A két színtér kiemelt fontossága mellett szól egyrészt, hogy a fiatalok nevelésére irányuló pedagógiai hatásrendszer akciói legnagyobb százalékban ebben a pedagógiai környezetben zajlanak, másrészt a család és az iskola együttesen érintett a magyar állampolgárokra nézve alaptörvényi szinten nevesített kötelességek teljesítésében. Mindössze három ilyen kötelesség van nevesítve az Alaptörvényben:

1. a haza védelme minden magyar állampolgárnak kötelessége;

2. a szülök kötelesek kiskorú gyermekük taníttatásáról gondoskodni;

3. a közterhekhez való hozzájárulási kötelezettség.

Napjainkban az iskolára nagy felelősség hárul a felnövekvő nemzedék ilyen irányú nevelésében, az etikus nemzettudat, a haza védelme felelösségének kialakításában. A hazafias eszmék megjelenítése a közösségi nevelés egyik formájának a hagyományos terepe; a nemzeti közösség fejlesztése a nemzetállamok Európáján belül minden nemzetállam oktatási rendszerének része valamilyen szinten. Bábosik István így fogalmazott: „A hazafias nevelés keretében lényegében a nemzet érdekeinek adekvát konstruktív szokások, példaképek, eszményképek és meggyőződések közvetítése, elfogadtatása és megerősítése folyik a gyakorlatban. Amennyiben ez a munka sikeres, a neveltek magatartása, tevékenysége, aktivitása közösségfejlesztő jelleget ölt, belső indíttatásra, külső ösztönzés vagy kontroll nélkül is, a kialakult demokratikus nemzeti beállítódás, illetve az azt alkotó értékes szükségletek befolyására. ${ }^{13}$ Ezért gondoljuk nagyon fontos célnak, hogy a Nemzeti alaptantervben megjelenített tartalmi szabályzók, közös követelmények a gyakorlatban hasznosítható ismereteket, élményeket, követhető példákat adjanak a hazában és a hazáért élö, dolgozó, tenni vágyó és tudó fiatalok számára."

\footnotetext{
${ }^{13}$ Bábosik István: Nemzettudat - nemzeti szocializáció - hazafiság. Iskolakultúra, 1998. 8. évf. 4. sz., 48. http:// real.mtak.hu/61926/1/EPA00011_iskolakultura_1998_04_040-048.pdf (Letöltés időpontja: 2019. 11. 02.)
} 


\section{FELHASZNÁLT IRODALOM}

Bábosik István: Nemzettudat - nemzeti szocializáció - hazafiság. Iskolakultúra, 1998. 8. évf. 4. sz. http://real.mtak.hu/61926/1/EPA00011_iskolakultura_1998_04_040-048.pdf

Csejtei Dezső: A haza minden elött. https://magyarnemzet.hu/velemeny/a-haza-minden-elott-7333160/ Eötvös József: A zsidók emancipációja. https://mek.oszk.hu/05900/05920/html/gmeotvosj0002.html Idegen Szavak Gyüjteménye. https://idegen-szavak.hu/kozmopolita

Kislexikon. http://www.kislexikon.hu/hazaszeretet.html

Scruton, Roger: Nélkülözhetetlen nemzetek. Magyar Szemle. Új folyam, 2013. XXII/7-8., augusztus, $52-76$.

Dr. Simicskó István: A hibrid hadviselés elözményei és aktualitásai. Hadtudomány, 2017/3-4., 3-16. DOI: 10.17047/HADTUD.2017.27.3-4.3

Dr. Simicskó István: Az országvédelem és országmozgósitás szervezeti, hatásköri, irányítási rendszere minösitett időszakokban (Történelmi korokon át napjaink hatályos szabályozásáig). Doktori (PhD-) értekezés, ZMNE, 2008.

Vitaanyag a globalizáció előnyünkre fordításáról. Európai Bizottság COM(2017) 240. 2017. 05. 10. https://ec.europa.eu/commission/sites/beta-political/files/reflection-paper-globalisation_hu.pdf 